\title{
Reply: LCN DNA: proof beyond reasonable doubt? - a response
}

\section{Carole McCartney}

I wish to respond to the comments on my Ethics Watch article (LCN DNA: proof beyond reasonable doubt? Nature Rev. Genet. 9, $325(2008))^{1}$ that were made by Peter Gill (LCN DNA: proof beyond reasonable doubt? - a response. Nature Rev. Genet. 20 Aug 2008 (doi:10.1038/nrg2362-c1)) $)^{2}$ The reporting, indeed the judicial summing up, in the Omagh bombing case might not have made it clear that there were full DNA profiles and this case might well be one in which the baby has been jettisoned along with the bathwater. However, justice demands that defendants not be convicted on unsound evidence. Although it is clear that low template DNA (LT-DNA) interpretation has a clear scientific basis, doubt seems to remain over the execution of the technique and, in forensic assays, this must be a crucial factor tending against admissibility in court. The review undertaken by Brian Caddy made 21 separate recommendations to try and ensure the uniformity of the technique between laboratories and its safety in forensic cases.

It is correct that the relevance within a prosecution of any declared DNA match is not a matter for the scientist, and indeed he can duly reduce the statistics to reflect the accommodations that are necessary when dealing with LT-DNA results. However, it remains the case that courtrooms are not the place for scientific debate over DNA profiling, or any 'science' for that matter. The personnel in the courtroom are not scientifically trained, trials are not impartial or objective fora, and juries (and indeed magistrates and the judiciary) are all too easily persuaded by impressive sounding statistical and scientific evidence.
It remains the province of the jury to decide upon the weight to be assigned to evidence presented and the courts have rejected any efforts to assist juries with proven methods for weighing evidence. While this remains the case (and it might not be ideal) a scientist must be cautious not to overstep the boundaries of their role, and the courts are mindful of telling juries how to handle evidence so as to prevent any interference with their role in deciding upon the ultimate issue. Serious debate should now proceed on how to prevent potential miscarriages of justice from the use (and abuse) of science in courtrooms. The Law Commission are set to launch a consultation on the use of expert evidence in the autumn, and it is hoped that their inquiries might give some guidance on an issue that demands urgent attention.

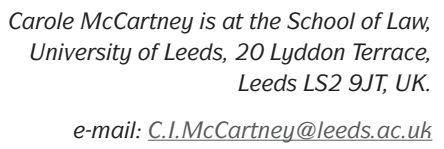

Carole McCartney is at the School of Law, University of Leeds, 20 Lyddon Terrace, Leeds LS2 9JT, UK.

e-mail:C.I.McCartney@leeds.ac.uk

McCartney, C. LCN DNA: proof beyond reasonable doubt? Nature Rev. Genet. 9, 325 (2008).

2. LCN DNA: proof beyond reasonable doubt? - a response. Nature Rev. Genet. 20 Aug 2008 (doi: 10.1038/nrg2362-c1). 